\title{
The isolation of enteroviruses from cases of acute conjunctivitis
}

\author{
P. G. HIGGINS AND R. J. D. SCOTT ${ }^{1}$
}

From the Virus Reference Laboratory, Central Public Health Laboratory, Colindale Avenue, London

SYNOPSIS In two epidemics of acute enterovirus conjunctivitis the diagnosis could only be estab-용 lished by the use of human embryonic organ cultures. In one instance cultures of ciliated respiratory $\stackrel{\sim}{\circ}$ epithelium proved sensitive to the virus but similar culture failed to support growth of the virus from the second outbreak which was isolated in organ cultures of conjunctiva.

The virus associated with a third outbreak had previously been isolated from the original materialo by culture in human embryo kidney cells, but it required passage in organ culture for its detection $\rightarrow$ after the specimens had been diluted.

The association of picornaviruses with two outbreaks of acute haemorrhagic conjunctivitis has recently been described (Yin-Murphy, 1972; Kono, Sasagawa, Ishii, Sigiura, Ochi, Mataumiya, Uchida, Kameyama, Kaneko, and Sakurai 1972). The recovery of virus on both these occasions was accomplished by the use of conventional tissue culturesHeLa cells in Singapore and cultures of human embryo kidney in Japan. However, the method which was successful in Singapore in $\mathbf{1 9 7 0}$ failed to reveal the causal organism when a second outbreak occurred there in 1971 (Yin-Murphy and Lim, 1972).

The purpose of this paper is to describe the successful application of organ cultures to the study of three outbreaks of acute conjunctivitis.

\section{Materials}

Specimens consisted of conjunctival swabs or scrapings in a transport medium and were received from three outbreaks of acute conjunctivitis.

The first outbreak from which material was examined occurred in England in 1971. Specimens from this episode had been studied extensively in tissue culture but only a few adenoviruses had been isolated (Dr D. A. McSwiggan, personal communication). Two of these specimens negative in tissue culture together with material from 13 fresh cases were received for further investigation.

Seven specimens from an outbreak in Djakarta 'Present address: Public Health Laboratory, Central Middlesex Hospital. Acton Lane, London NW10.

Received for publication 26 June 1973. in 1972 were collected and submitted by Professor Barrie Jones.

Twenty specimens from the second outbreak क्षे Singapore referred to above had previously been. examined in this laboratory by $\operatorname{Dr} M$. S. Perefact and nine entero-like viruses producing a cytopathic effect in cultures of human embryo kidney had been isolated (personal communication). Because of the $\frac{0}{\varnothing}$ reduced quantity of these specimens it was necessary to dilute them to provide sufficient material forō complete re-examination.

\section{Direct Inoculation of Tissue Cultures}

Of the specimen, $0 \cdot 1-0 \cdot 2 \mathrm{ml}$ was inoculated into a single tube of each of the following cultures: HeLa cells, primary monkey kidney, human diploiō. fibroblasts $\left(\mathrm{WI}_{38}\right)$, and human embryo kidney. The inoculated cultures were rolled at $33^{\circ} \mathrm{C}$ and examine 5 for at least 14 days before being discarded as negative.

\section{Organ Cultures}

HUMAN EMBRYONIC

Ciliated respiratory epithelium

Organ cultures were prepared from the nose and trachea of human embryos as previously describee (Higgins and Ellis, 1973).

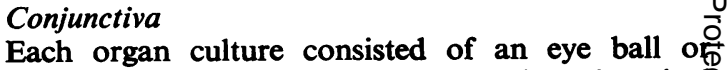
eyelids together with its covering of conjunctiva 
epithelium so that four organ cultures could be prepared from each foetus.

\section{Small intestine}

The ileum was dissected from its mesentery, carefully opened along its longitudinal axis and divided into approximately $1 \mathrm{~cm}$ lengths.

\section{SIMIAN}

Organ cultures were made from trachea, eyeballs, and eyelids of rhesus monkeys in exactly the same manner as the human organ cultures. However, because of their size, only the anterior portion of the eye was used and the upper and lower eyelids made separate organ cultures.

All organ cultures were placed in $6 \times \frac{5}{8}$ in. test tubes closed by rubber bungs and maintained on Eagle's minimal essential medium with $0.88 \%$ sodium bicarbonate, $0.2 \%$ plasma bovine albumin, penicillin, and streptomycin. Cultures were rolled at $33^{\circ} \mathrm{C}$, and, following inoculation with approximately $0.2 \mathrm{ml}$ of specimen, the fluid was harvested and replaced with fresh medium every two to three days for 10 days. The harvests from any one culture were pooled and tested in the same tissue cultures as used for the attempted isolation of virus from the original specimen.

\section{Results}

\section{ENGLISH OUTBREAK}

Direct inoculation of tissue cultures

Three viruses were isolated on the initial examination of the 15 specimens received. Two of the viruses were adenoviruses, one type 4 and one type 7 , while the third virus, which produced a cytopathic effect in $\mathrm{WI}_{38}$ cultures only, had the characteristics of an enterovirus.

\section{Human embryonic organ culture}

The 15 specimens were inoculated into organ cultures of human embryonic ciliated respiratory epithelium and, if negative, given at least one and commonly three further passages in similar organ cultures. All specimens which failed to yield a virus were re-tested in organ cultures from another foetus in case they varied in their sensitivity to this virus. In addition to the two adenoviruses, six enteroviruses were isolated including the one previously detected by the direct inoculation of tissue cultures. Four of the six isolates were reisolated from the original specimen, on at least one occasion.

Following the examination of the specimens from Djakarta it was considered advisable that all specimens which were negative or from which we had failed to re-isolate the virus should be examined in organ cultures of human embryonic conjunctiva. Unfortunately very little of the specimens remained at this time so that the inoculum was small and no virus was recovered from the initial organ culture fluid or following its passage into organ cultures of ciliated epithelium. The results obtained from the study of the specimens from the English outbreak are summarized in table I.

\begin{tabular}{|c|c|c|c|c|c|c|c|}
\hline \multirow[t]{2}{*}{ Specimen } & \multirow[t]{2}{*}{ Tissue Culture } & \multicolumn{4}{|c|}{ Ciliated Epithelial Organ Culture } & \multirow{2}{*}{$\begin{array}{l}\text { Conjunctival } \\
\text { Organ Culture }\end{array}$} & \multirow{2}{*}{$\begin{array}{l}\text { Passage } \\
\text { to Ciliated } \\
\text { Epithelial } \\
\text { Organ Culture }\end{array}$} \\
\hline & & Initial & $\begin{array}{l}\text { First } \\
\text { Passage }\end{array}$ & $\begin{array}{l}\text { Second } \\
\text { Passage }\end{array}$ & $\begin{array}{l}\text { Third } \\
\text { Passage }\end{array}$ & & \\
\hline 20254 & - & $\begin{array}{l}-(2) \\
+(2)\end{array}$ & $+(1)-(1)$ & $+(1)$ & & & \\
\hline $\begin{array}{l}20255 \\
23351\end{array}$ & $\overline{-}$ & $\begin{array}{l}-(4) \\
+(1) \\
-(3)\end{array}$ & $\begin{array}{l}+(1)-(2) \\
+(1) \\
-(2)\end{array}$ & $+(1)$ & & - & - \\
\hline $\begin{array}{l}23352 \\
23353\end{array}$ & $\overline{-}$ & $\begin{array}{l}-(3) \\
-(2) \\
+(2)\end{array}$ & $\begin{array}{l}-(2) \\
-(1)+(1)\end{array}$ & $-(1)$ & $-(1)$ & - & - \\
\hline $\begin{array}{l}23354 \\
23355 \\
23356\end{array}$ & $\overline{-}$ & $\begin{array}{l}-(4) \\
-(4) \\
+(3)\end{array}$ & $\begin{array}{l}-(4) \\
-(3) \\
+(1)\end{array}$ & $\begin{array}{l}-(2) \\
-(2)\end{array}$ & $\begin{array}{l}-(2) \\
-(1)\end{array}$ & $\overline{-}$ & - \\
\hline 23357 & - & $-(4)$ & $-(4)$ & $-(2)$ & $-(2)$ & - & - \\
\hline 23358 & - & $-(3)$ & $-(2)$ & $-(1)$ & $-(1)$ & - & - \\
\hline $\begin{array}{l}23359 \\
23360\end{array}$ & $\overline{-}$ & $\begin{array}{l}-(3) \\
-(2)\end{array}$ & $\begin{array}{l}-(2) \\
-(2)\end{array}$ & $-(1)$ & $-(1)$ & - & $\overline{-}$ \\
\hline 23361 & Adenovirus type 4 & $\begin{array}{l}\text { Adenovirus } \\
\text { type } 4 \text { (2) }\end{array}$ & & & & & \\
\hline 23362 & - & $\begin{array}{l}-(1) \\
+(3)\end{array}$ & & & & & \\
\hline 23363 & Adenovirus type 7 & $\begin{array}{l}\text { Adenovirus } \\
\text { type } 7 \text { (2) }\end{array}$ & & & & & \\
\hline
\end{tabular}

Table I Isolations of viruses from specimens from an outbreak of conjunctivitis in England in 1971

$+=$ isolation of enterovirus

Figures in parentheses $=$ number of cultures 


\begin{tabular}{|c|c|c|c|c|c|c|}
\hline \multirow[t]{2}{*}{ Specimen } & \multirow[t]{2}{*}{ Tissue Culture } & \multicolumn{3}{|c|}{ Ciliated Epithelial Organ Culture } & \multirow{2}{*}{$\begin{array}{l}\text { Conjunctival Organ } \\
\text { Culture }\end{array}$} & \multirow{2}{*}{$\begin{array}{l}\text { Passage to Ciliated } \\
\text { Epithelial Organ Culture }\end{array}$} \\
\hline & & Initial & First Passage & Second Passage & & \\
\hline $\begin{array}{l}13486 \\
13487 \\
13488 \\
13489 \\
13490 \\
13491 \\
13492\end{array}$ & $\begin{array}{l}- \\
- \\
- \\
- \\
- \\
- \\
\text { CT }\end{array}$ & $\begin{array}{l}-(3) \\
-(3) \\
-(3) \\
-(3) \\
-(3) \\
-(3) \\
C T\end{array}$ & $\begin{array}{l}-(2) \\
-(2) \\
-(2) \\
-(1) \\
-(1) \\
-(1)\end{array}$ & $\begin{array}{l}-(1) \\
-(1) \\
-(1) \\
-(1) \\
-(1) \\
-(1)\end{array}$ & $\begin{array}{l}+(1) \\
+(1) \\
-(1) \\
+(1) \\
+(1) \\
-(3) \\
\text { CT }\end{array}$ & $\begin{array}{l}+(1) \\
+(1) \\
+(1) \\
+(1) \\
+(1) \\
-(3)\end{array}$ \\
\hline
\end{tabular}

Table II Isolations of viruses from specimens from an outbreak of conjunctivitis in Djakarta in 1972

CT = contaminated

$t=$ isolation of enterovirus

Figures in parentheses $=$ number of cultures

DJAKARTA OUTBREAK

One of the seven specimens received caused fungal contamination of all the cultures into which it was inoculated and could not be examined.

Direct inoculation of tissue cultures

No virus was isolated from any of the six specimens.

\section{Human embryonic organ culture}

Each of the six specimens was inoculated into organ cultures of human embryonic nose or trachea on three different occasions one of which was passaged through two further organ cultures. No virus was isolated at any passage level.

Similarly all specimens were inoculated into organ cultures of human embryonic conjunctiva and four of the six specimens yielded an enteroviruslike agent on testing the organ culture fluid in tissue cultures. A further strain of the virus was isolated following passage of the conjunctiva organ culture fluid to nasal organ culture. No virus was isolated from the remaining specimen even after examination in three different conjunctival organ cultures or after their subsequent passage in nasal organ cultures.

The results obtained from the study of the specimens from the Djakarta outbreak are summarized in table II.

SECOND OUTBREAK IN SINGAPORE

What remained of each of the 20 specimens after prior investigation was diluted 1 in 2 or 1 in 10 .

\section{Direct inoculation of tissue cultures}

No virus was isolated from any of the diluted material.

\section{Human embryonic organ culture}

All specimens were inoculated into organ cultures of nose or trachea and conjunctiva. Those organ culture fluids which failed to produce a cytopathic effect in tissue culture were passaged in the same type of organ culture. In all seven enteroviruses $N$ were isolated, five in organ cultures of ciliated 0 epithelium and two in conjunctiva organ cultures. Both strains isolated in conjunctiva organ cultures were detected in the fluid from the initial organ $\frac{}{5}$ culture but two strains recovered from organ $\vec{\omega}$ cultures of ciliated epithelium were isolated only after passage.

Of the nine specimens previously found positive by Dr Pereira five were diluted 1 in 2 before re- $\subseteq$ examination and three still yielded virus in organ $\vec{\varphi}$ culture but not on direct inoculation of tissue culture. The remaining four specimens were diluted 1 in 10 and no virus was recoverd. Four straims not previously detected were isolated by the use of organ culture; all from material which had not been diluted greater than 1 in 2 .

The results are summarized in table III.

SENSITIVITY OF ORGAN CULTURES OF HUMAN EMBRYONIC INTESTINE

As the viruses isolated had the characteristics of enteroviruses their growth in organ cultures of human intestine was studied. Four specimens from $\frac{}{0}$ the English outbreak known to contain virus and 3 . four similar specimens from the Djakarta outbreak were seeded into organ cultures of human embryo $₹$ intestine. No virus was isolated from the gut organ $\mathrm{O}$ culture fluids which were then passaged into organ cultures of nose or trachea, or conjunctiva, and in $\frac{D}{0}$ two instances into both. The fluids from the passage organ cultures yielded virus in one instance only, $\sigma$ one of the Djakarta strains, which grew in both $N$ ciliated and conjunctival epithelium.

The results are summarized in table IV.

SENSITIVITY OF SIMIAN ORGAN CULTURES Three specimens from the English outbreak, only one of which was known to contain virus, were inoculated into organ cultures of rhesus monkey trachea. No virus was isolated from the organ culture fluids or after their passage in further organ $\frac{\varrho}{\mathscr{D}}$ 


\begin{tabular}{|c|c|c|c|c|c|c|}
\hline \multirow[t]{2}{*}{ Specimen } & \multirow[t]{2}{*}{ Dilution of Specimens } & \multirow[t]{2}{*}{ Tissue Culture } & \multicolumn{2}{|c|}{ Ciliated Epithelial Organ Culture } & \multicolumn{2}{|c|}{ Conjunctival Organ Culture } \\
\hline & & & Initial & First Passage & Initial & First Passage \\
\hline $\mathbf{E C}^{\mathbf{1}}$ & $1 / 10$ & - & - & - & - & - \\
\hline EC2 & $1 / 2$ & - & - & - & + & - \\
\hline EC5 $^{1}$ & $1 / 2$ & - & - & - & - & - \\
\hline EC6 $^{1}$ & $1 / 10$ & - & - & - & - & - \\
\hline$E C 7^{1}$ & $1 / 2$ & - & + & & - & - \\
\hline EC8 & $1 / 10$ & - & - & - & - & - \\
\hline EC9 & $1 / 2$ & - & - & - & - & - \\
\hline $\mathrm{EC}^{1} 0^{1}$ & $1 / 10$ & - & - & - & - & - \\
\hline EC11 & $1 / 2$ & - & - & + & - & - \\
\hline EC12 & $1 / 2$ & - & + & & - & - \\
\hline EC14 & $1 / 2$ & - & - & - & - & - \\
\hline $\mathrm{EC} 17^{1}$ & $1 / 2$ & - & - & - & - & - \\
\hline EC20 & $1 / 2$ & - & + & & - & - \\
\hline EC21 ${ }^{1}$ & $1 / 10$ & - & - & - & - & - \\
\hline EC26 1 & $1 / 2$ & - & - & - & + & \\
\hline EC27 & $1 / 2$ & - & - & - & - & - \\
\hline EC80 & $1 / 2$ & - & - & + & - & - \\
\hline EC81 & $1 / 2$ & - & - & - & - & - \\
\hline EC82 & $1 / 2$ & - & - & - & - & - \\
\hline EC83 & $1 / 2$ & - & - & - & - & - \\
\hline
\end{tabular}

Table III Isolations of viruses from specimens from an outbreak of conjunctivitis in Singapore in 1971

$+=$ isolation of enterovirus

${ }^{1}$ Enteroviruses isolated in tissue cultures of HEK on examination of undiluted material by Dr M. S. Pereira

\begin{tabular}{|c|c|c|c|c|}
\hline Specimen & Outbreak & $\begin{array}{l}\text { Human Embryonic Gut Organ } \\
\text { Culture }\end{array}$ & $\begin{array}{l}\text { Passage to Nose or Trachea } \\
\text { Organ Culture }\end{array}$ & Passage to Conjunctival Organ Culture \\
\hline 23351 & England & - & - & \\
\hline 23353 & , & - & - & \\
\hline 23356 & $"$ & - & - & \\
\hline 23362 & & - & - & \\
\hline 13486 & Djakarta & - & & - \\
\hline 13487 &, & - & + & + \\
\hline 13489 & $"$ & - & - & - \\
\hline 13490 & " & - & & - \\
\hline
\end{tabular}

Table IV Efficiency of organ cultures of human embryonic small intestine $+=$ recovery of virus

cultures of simian trachea. Three specimens from each of the English and Djakarta outbreaks, all known to contain virus, were inoculated into organ cultures of rhesus monkey conjunctiva. No virus was isolated on examination of the organ culture fluids but two of the fluids from subsequent passage in humanembryonic ciliated epithelium did yield virus. The results are summarized in table V.
PATTERN OF GROWTH OF ENTERO-LIKE VIRUSES IN ORGAN CULTURE

An estimated 100 TCID $_{50}$ of one English strain and one Djakarta strain were inoculated into organ cultures. After two hours the medium was removed, the culture washed, and $1 \mathrm{ml}$ of fresh medium introduced. The medium was changed every 24 hours for 10 days and the amount of virus which

\begin{tabular}{llllll}
\hline Specimen & \multicolumn{2}{l}{ Trachea Organ Culture } & Specimen & Conjuctival Organ Culture & $\begin{array}{c}\text { Passage to Human Embryonic } \\
\text { Nasal Organ Culture }\end{array}$ \\
\cline { 2 - 5 } & Initial & First Passage & & & \\
\hline 23356 & - & - & 20254 & - & + \\
23358 & - & - & 23353 & - & - \\
23359 & - & - & 23356 & - & - \\
& & & 13486 & - & - \\
\hline
\end{tabular}

Table $\mathrm{V}$ Efficiency of simian organ cultures

$+=$ recovery of virus 


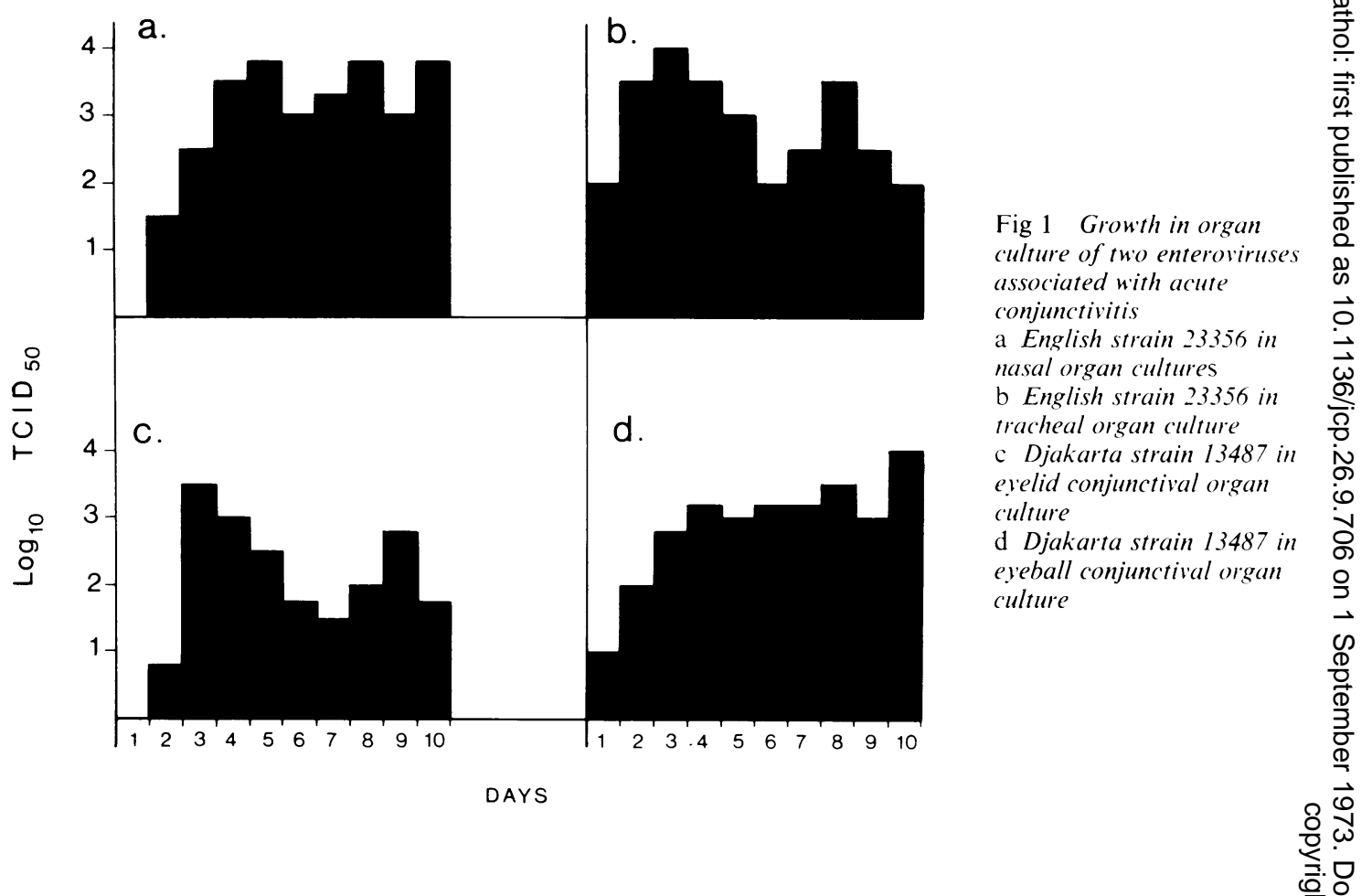

had been produced and survived during the previous 24 hours was assayed.

The growth pattern of one English strain, 23356, in nose and trachea and one Djakarta strain, 13487 , in eye and eyelid are shown in figure 1a-d. Each culture absorbed between 30 and 150 TCID $_{50}$ of virus but produced more than 3000 TCID $_{50}$ of virus on at least one of the subsequent 10 days. In every case virus could be detected from the second to the tenth day after inoculation.

\section{Discussion}

The diagnosis of the English and the Djakarta outbreaks of conjunctivitis could not be accomplished with certainty on the results obtained by the direct inoculation of tissue cultures but was clearly established by the use of organ cultures. The isolation rate was high, five out of six specimens studied from the Djakarta outbreak, and may have been higher from the other episode had more material been available. Even so, an enterovirus was isolated from almost $50 \%$ of those specimens from the English outbreak which did not contain an adenovirus - sufficient to establish the cause.

Prior examination of the material from the second outbreak in Singapore had resulted in the isolation of nine enteroviruses in cultures of human embryo kidney. No virus was isolated on direct inoculations of tissue cultures in this study but this could have resulted from the dilution of the remaining materia before re-examination. This view is supported by the fact that virus was recovered in organ cultures from three of the five known positive specimens 3 which were diluted 1 in 2 but from none of the fou? positive specimens diluted 1 in 10 . Although we. failed to isolate virus from two of the known positive specimens diluted 1 in 2 a further four viruses were isolated in organ cultures which had not been detected when cultures of human embryos kidney had been inoculated with the originas undiluted material.

This situation is analogous to the diagnosis of rhinovirus infections where many more infectionso can be diagnosed by the additional use of organ cultures of ciliated respiratory epithelium than byo the inoculation of tissue cultures alone (Tyrrell and Bynoe, 1966; Higgins, 1966). Because of the simil-Nي arity in the pattern of isolation of these entero- $\omega$ viruses and the rhinoviruses it would be expected that some strains of enterovirus will be detected in tissue culture and not in organ cultures as is knowne? to occur with the rhinoviruses (Higgins, Ellis, and Woolley, 1969).

The viruses isolated from these three outbreaksi़ and the Japanese strains are closely related, if not 
identical, and probably distinct from any previously known enterovirus (Higgins et al, unpublished; Kono et al, 1972). However, they exhibited differing requirements for primary isolation: the Japanese strains grew on direct inoculation of tissue cultures, all but one of the English strains isolated required organ cultures of ciliated epithelium while the Djakarta strains could only be detected after passage in conjunctiva organ cultures. A simular situation is known to exist with the rhinoviruses where one strain of a particular serotype can be isolated on direct inoculation of tissue culture but another strain of the same serotype will require organ culture for its recovery (Higgins, 1966).

It may appear surprising that an enterovirus will grow preferentially in organ cultures of respiratory epithelium when others are known to be more readily detected by the inoculation of tissue culture or suckling mice (Higgins et al, 1969). However, it has recently been reported that Echo virus type 23 , when associated with respiratory infections, can be isolated more readily by such organ cultures than by the direct inoculation of tissue culture (Higgins and Ellis, 1973).

Organ cultures of human embryonic intestine have been shown to support the growth of some enteroviruses (Rubenstein and Tyrrell, 1970) but only limited success was obtained with this particular virus and this could reflect its adaptation to the conjunctiva. Similarly, organ cultures of simian origin were of no value in the isolation of this virus although growth is assumed to have occurred on two occasions as the fluid from these cultures did yield virus after passage in cultures derived from human embryos.

The enteroviruses isolated from all three out- breaks have many properties in common with those isolated in Singapore, Hong Kong, and Japan. They appear to constitute a cause of conjunctivitis which has only recently been recognized and which, on occasion, can most readily be diagnosed by the use of organ cultures, the type of culture itself also determining the success of the investigation. However, supplies of human embryonic material are limited and it is suggested that, as in the study of rhinovirus infections, only those specimens which are negative on examination in tissue culture should be inoculated into organ cultures.

We are grateful to Dr H. E. M. Kay, Royal Marsden Hospital, for supplies of foetal tissue.

\section{References}

Higgins, P. G. (1966). The isolation of viruses from acute respiratory infections. Part V. The use of organ cultures of human embryonic nasal and tracheal ciliated epithelium. Mth. Bull. Minist. Hlth Lab. Serv., 25, 283-288.

Higgins, P. G., and Ellis, E. M. (1973). Further observations on the use of organ cultures in the study of acute respiratory infections. J. med Microbiol., 6, 177-185.

Higgins, P. G., Ellis, E. M., and Woolley, D. A. (1969). A comparative study of standard methods and organ culture for the isolation of respiratory viruses. J. med. Microbiol., 2, 109-115.

Kono, R., Sasagawa, A., Ishii, K., Sigiura, S., Ochi, M., Mataumiya, H., Uchida, Y., Kameyama, K., Kaneko, M., and Sakurai, N. (1972). Pandemic of new type of conjunctivitis. Lancet, 1, 1191-1194.

Rubenstein, D., and Tyrrell, D. A. J. (1970). Growth of viruses in organ cultures of intestine. Brit. J. exp. Path., 51, 210-216.

Tyrrell, D. A. J., and Bynoe, M. L. (1966). Cultivation of viruses from a high proportion of patients with colds. Lancet, 1 , 76-77.

Yin-Murphy, M. (1972). An epidemic of picornavirus conjunctivitis in Singapore. S. East Asian J. trop.Med. publ. Hlth, 3, 303-309.

Yin-Murphy, M., and Lim, K. H. (1972). Picornavirus epidemic conjunctivitis in Singapore. Lancet, 2, 857-858. 